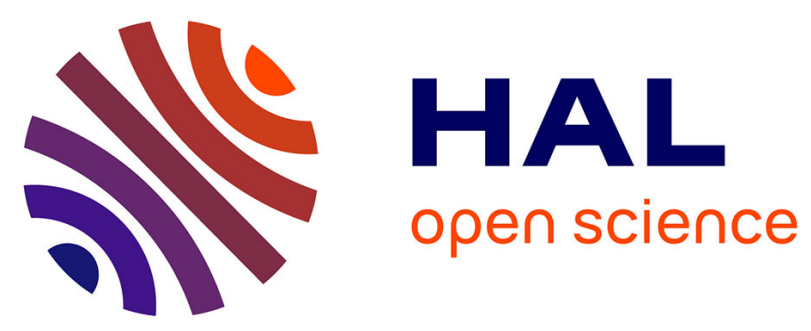

\title{
A convenient extension of the Wessely-Moser rearrangement for the synthesis of substituted alkylaminoflavones as neuroprotective agents in vitro
}

Ronan Larget, Brian Lockhart, Pierre Renard, Martine Largeron

\section{- To cite this version:}

Ronan Larget, Brian Lockhart, Pierre Renard, Martine Largeron. A convenient extension of the Wessely-Moser rearrangement for the synthesis of substituted alkylaminoflavones as neuroprotective agents in vitro. Bioorganic and Medicinal Chemistry Letters, 2000, 10 (8), pp.835-838. 10.1016/S0960-894X(00)00110-4 . hal-02385135

\section{HAL Id: hal-02385135 \\ https://hal.science/hal-02385135}

Submitted on 8 Feb 2021

HAL is a multi-disciplinary open access archive for the deposit and dissemination of scientific research documents, whether they are published or not. The documents may come from teaching and research institutions in France or abroad, or from public or private research centers.
L'archive ouverte pluridisciplinaire HAL, est destinée au dépôt et à la diffusion de documents scientifiques de niveau recherche, publiés ou non, émanant des établissements d'enseignement et de recherche français ou étrangers, des laboratoires publics ou privés. 


\title{
A CONVENIENT EXTENSION OF THE WESSELY-MOSER REARRANGEMENT FOR THE SYNTHESIS OF SUBSTITUTED ALKYLAMINOFLAVONES AS NEUROPROTECTIVE AGENTS IN VITRO.
}

\author{
Ronan Larget ${ }^{\mathrm{a}}$, Brian Lockhart ${ }^{\mathrm{b}}$, Pierre Renard ${ }^{\mathrm{c}}$ and Martine Largeron ${ }^{\mathrm{a}}{ }^{*}$ \\ a Laboratoire de Chimie Analytique et Electrochimie, UMR 8638 CNRS-Université René Descartes, \\ Faculté des Sciences Pharmaceutiques et Biologiques, 4, Avenue de l'Observatoire, F-75270 Paris Cedex06

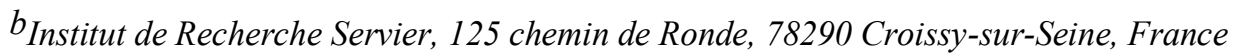 \\ ${ }^{c}$ ADIR, 1 rue Carle Hébert, 92415 Courbevoie Cedex, France.
}

\begin{abstract}
A series of 8-alkylamino-5,7-dihydroxyflavones was prepared from chrysine via a seven step sequence. The synthesis of their 6-alkylamino isomers could be subsequently accomplished through a convenient extension of the Wessely-Moser rearrangement. These compounds were found to be efficient neuroprotective agents in vitro.
\end{abstract}

Keywords : Antioxidants, Neuroprotective agents, Radical scavengers, Substituent effects.

There is now substantial evidence accumulating to suggest that oxidative stress may play a role in the progression of many neurodegenerative pathologies of the central nervous system, including Parkinson's disease and Alzheimer's disease. ${ }^{1}$ Consequently, supplementation with exogenous antioxidants can represent an important therapeutic potential to minimize central nervous system damage. So, there is considerable interest in the discovery and development of efficient antioxidants.

In the course of our search for new neuroprotective agents, 2,3 we recently reported the synthesis of novel 8-alkylamino-3-substituted-1,4-benzoxazine derivatives I as well as 3-alkylamino-2,4-dihydroxybenzophenones II (Figure). ${ }^{4-6}$<smiles>[R]Nc1ccc(C(=O)c2ccccc2)c2c1OCC([R])([R])N2C</smiles>

I<smiles>[R]Nc1c(O)ccc(C(=O)c2ccccc2)c1O[2H]</smiles>

II

Figure

From their capacity to inhibit oxidative stress-mediated neuronal degeneration in vitro, these compounds were found to be potent neuroprotective agents with activity close to that of standard $\alpha$ tocopherol.7,8 From these studies, substituted-1,4-benzoxazines I were identified as the most promising compounds for therapeutic potential owing to their very low intrinsic cytotoxicity. ${ }^{8,9}$ Although 3alkylaminophenols II were found to be at least ten fold more toxic than the series of 1,4-benzoxazines, they

*Fax : 01432905 92,E-mail : largeron@pharmacie.univ-paris5.fr 
remained potent neuroprotective agents. ${ }^{7}$ So, we envisioned potentially useful structural modifications in order to enhance antioxidant activity. We thought that it would be then possible to determine a concentration range for which antioxidant effects could be achieved without the manifestation of intrinsic toxicity. Toward this goal, we planned to synthesize 6-alkylamino-5,7-dihydroxyflavones 10a-e (Scheme 1). Flavonoids, in particular polyhydroxyflavones such as quercetin, morin, myricetin and kempferol, are indeed well known to exhibit antioxidant activity. ${ }^{10-12}$ This raised the question of whether or not 6-alkylaminoflavones 10a-e in general would be more promising derivatives than their benzophenone analogues II.

In this paper, we wish to report the synthesis of 6-alkylamino-5,7-dihydroxyflavones 10a-e that has been successfully accomplished from their 8-alkylamino isomers through a convenient extension of the Wessely-Moser rearrangement. We also disclose the neuroprotective properties of these compounds as part of our continuing research efforts to find safe and effective neuroprotective agents.

\section{Chemistry}

At the ouset, our synthetic strategy for the preparation of compounds 10a-e involved the intermediary synthesis of 5,7-dihydroxy-6-nitroflavone, which appeared deceptively simple. This should be further reduced to 6-amino-5,7-dihydroxyflavone, and then alkylated by the appropriate methods leading to the expected compounds 10a-e (Scheme 1).
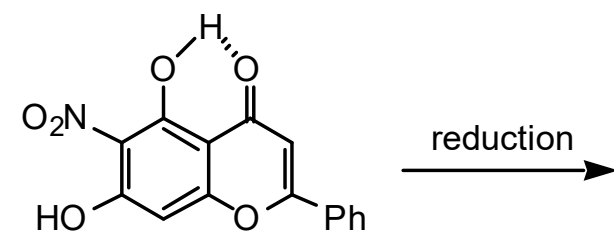<smiles>Nc1c(O)cc2oc(-c3ccccc3)cc(=O)c2c1[18OH]</smiles>

Scheme 1

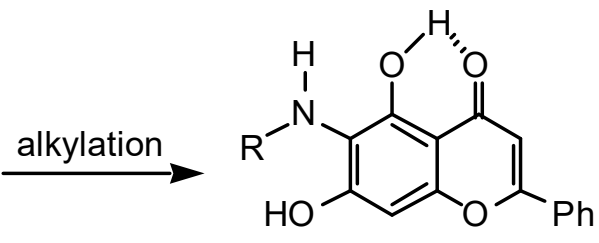

10a-e

Currently available methods to prepare 5,7-dihydroxy-6-nitroflavone from 2,4,6-trihydroxy-3nitroacetophenone including Baker-Venkataraman rearrangement, ${ }^{13}$ synthesis from chalcones ${ }^{14}$ and synthesis via an intramolecular Wittig strategy ${ }^{15}$ met with total failure. Furthermore, newer methods for directly converting 2,4,6-trihydroxy-3-nitroacetophenone into the required 1,3-diketone intermediate, such as organolithium reagents ${ }^{16}$, or phase-transfer catalysis ${ }^{17}$, proved to be ineffective. At this juncture, an alternative route which involved the functionalization of chrysine 1 was followed for the preparation of 5,7dihydroxy-6-nitroflavone (scheme 2). Unfortunately, the nitration of chrysine 1 with fuming $\mathrm{HNO}_{3}$ in acetic acid gave the desired 5,7-dihydroxy-6-nitroflavone as a minor product (2\% yield), while the unwanted 8nitro isomer 2 was isolated as the main product (70\% yield). ${ }^{18}$ Nevertheless, in view of the relative ease of preparation of 8-alkylamino-5,7-dihydroxyflavones from 8-nitrochrysine $\mathbf{2}$, the synthesis of isomers 8a-e was pursued for two reasons. First, encouraged by the results of Wessely and Moser which previously observed the conversion of 5,7,8-trimethoxyflavone into the 5,6,7-trihydroxy compound on demethylation, ${ }^{19}$ we thought that 8 -alkylaminoflavones 8a-e possibly could serve as starting materials for the preparation of their 6-isomers 10a-e. Second, compounds 8a-e could be interesting to explore the relationship between the position of the alkylamino chain and the neuroprotective activity. Accordingly, 8alkylaminoflavones 8a-e were synthesized from 8-nitrochrysine 2 via a six step sequence, which involved 
protection and deprotection steps as reported in scheme 2. Alkylation of 8-nitrochrysine 2 with $\mathrm{Me}_{2} \mathrm{SO}_{4}$ and $\mathrm{K}_{2} \mathrm{CO}_{3}$, followed by reduction of the nitro group with stannous choride in ethanol, ${ }^{20}$ afforded 4 in roughly $60 \%$ overall yield. The latter was alkylated, after protection with the 2,4-dinitrobenzenesulfonyl group that could be further cleaved under mild conditions. ${ }^{21} \mathrm{~N}$-monosubstituted 2,4-dinitrobenzenesulfonamide 5 , readily prepared in 88\% yield from 8-amino-5,7-dimethoxyflavone 4 and 2,4-dinitrobenzenesulfonyl chloride, could be efficiently $N$-alkylated with appropriate primary alkyl halides by the conventional methods, in roughly $85 \%$ yield. For the introduction of the isopropyl chain, compound $\mathbf{5}$ was alkylated under the Mitsunobu conditions, ${ }^{22}$ leading to compound $\mathbf{6 a}$ in $77 \%$ yield. Facile deprotection of $N, N$-disubstituted2,4-dinitrobenzenesulfonamides 6a-e was achieved by treatment with mercaptoacetic acid and triethylamine in dichloromethane, giving the required compounds $7 \mathbf{a}-\mathbf{e}\left(71-94 \%\right.$ yields). ${ }^{21}$ Finally, complete demethylation of compounds $\mathbf{7 a - d}$ was successfully performed using 5 equiv. of $\mathrm{AlCl}_{3}$, in toluene heated at reflux, to afford compounds 8a-d, in yields ranging from 68 to 92\%. In the specific case of compound 7e, bearing an allyl chain, demethylation with 5 equiv. of $\mathrm{BBr}_{3}$ in dichloromethane at room temperature led to compound $\mathbf{8 e}$ in $70 \%$ yield.<smiles>O=c1cc(-c2ccccc2)oc2cc(O)cc([18OH])c12</smiles>

1<smiles>[R]N(c1c(OC)cc(OC)c2c(=O)cc(-c3ccccc3)oc12)S(=O)(=O)OCc1ccccc1</smiles>

6a-e

(f)<smiles>[R]Nc1c(OC)cc(OC)c2c(=O)cc(-c3ccccc3)oc12</smiles>

7a-e (a)<smiles></smiles>

2<smiles>COc1cc(OC)c2c(=O)cc(-c3ccccc3)oc2c1NP(=O)(O)OCc1ccccc1</smiles>

5<smiles>[R]Nc1c(O)cc(O[14CH])c2c(=O)cc(-c3ccccc3)oc12</smiles>

(b)<smiles>COc1cc(OC)c2c(=O)cc(-c3ccccc3)oc2c1[N+](=O)[O-]</smiles>

3

(c)<smiles>COc1cc(OC)c2c(=O)cc(-c3ccccc3)oc2c1N</smiles>

4 (g)

8a-e (d)<smiles>C=CC</smiles>

Scheme 2

(a) $\mathrm{HNO}_{3} 70 \%, \mathrm{AcOH}, 65^{\circ} \mathrm{C}, 1 \mathrm{~h}, 70 \%$; (b) $\mathrm{Me}_{2} \mathrm{SO}_{4}, \mathrm{~K}_{2} \mathrm{CO}_{3}, \mathrm{DMF}$, room temperature, 3h, 81\%; (c) $\mathrm{SnCl}_{2} .2 \mathrm{H}_{2} \mathrm{O}, \mathrm{EtOH}$, reflux, 5h, 71\%; (d) 2,4-( $\left.\mathrm{NO}_{2}\right)_{2} \mathrm{PhSO}_{2} \mathrm{Cl}$, pyridine, $\mathrm{CH}_{2} \mathrm{Cl}_{2}$, room temperature, $8 \mathrm{~h}, 88 \%$; (e) $\mathrm{RI}, \mathrm{K}_{2} \mathrm{CO}_{3}$, DMF, room temperature, 1 - 
16h, 83-87\% or $\mathrm{Pr}^{\mathrm{i}} \mathrm{OH}, \mathrm{DEAD}, \mathrm{PPh}_{3}$, THF, reflux, 3h, 77\%; (f) $\mathrm{HSCH}_{2} \mathrm{COOH}, \mathrm{Et}_{3} \mathrm{~N}, \mathrm{CH}_{2} \mathrm{Cl}_{2}$, room temperature, 5-16h, 71$94 \%$; (g) $\mathrm{AlCl}_{3}$, toluene, reflux, $68-92 \%$ or $\mathrm{BBr}_{3}, \mathrm{CH}_{2} \mathrm{Cl}_{2}$, room temperature, $4-5 \mathrm{~h}, 50-70 \%$.

Having established the seven step sequence for the synthesis of 8-alkylamino-5,7-dihydroxyflavones 8a-e, we next turned our attention to the hypothetical conversion of these compounds to their 6-alkylamino isomers 10a-e. It has been found for a long time that flavonoids having the 5,7,8-arrangement of methoxy groups suffered isomeric change, on demethylation, yielding a product with the 5,6,7-arrangement. This conversion, known as the Wessely-Moser rearrangement, ${ }^{19}$ was essentially used for the elucidation of structures of flavonoids and was further extended to chromones, xanthones and derivatives. ${ }^{23-26}$ Surprisingly, little attention has been devoted to this rearrangement, as a surrogate of direct synthesis, when the latter was cumbersome and inefficient. ${ }^{26,27}$ Furthermore, use of the Wessely-Moser rearrangement has been restricted in general to compounds bearing hydroxy or methoxy groups.

Initial attempts to perform the Wessely-Moser rearrangement on 8-nitroflavone 3 were to no avail: in no cases, were we able to detect a trace of the expected 6-nitro isomer. So, we decided to investigate the conversion of 8 -alkylamino derivatives $7 \mathbf{a}$-e, by the action of boiling hydrochloric acid. In all cases, the isomeric change took place leading to 6-alkylaminoflavones 9a-e, in good yields ranging from 60 to $74 \%$. Finally, synthesis of 6-alkylamino isomers 10a-e could be achieved through demethylation at the 7-position, under the conditions reported above 28 (scheme 3 ).

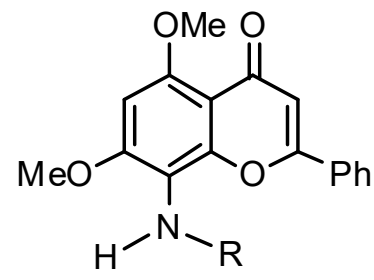

7a-e

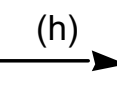

9a-e

Scheme 3<smiles>[R]Nc1c(OC)cc2oc(-c3ccccc3)cc(=O)c2c1[2H]</smiles>

$\stackrel{(g)}{\longrightarrow}$

10a-e

(h) conc. $\mathrm{HCl}$, reflux, 30-64h, 60-74\%.

\section{In vitro biological results}

The intrinsic neurotoxicity as well as the neuroprotective activity of 8 -alkylaminoflavones 8a-e and 6-alkylaminoflavones 10a-e were assessed in vitro on murine HT-22 hippocampal cell cultures ${ }^{29}$ and compared with those of benzophenone analogues II. The results are presented in Table.

In order to determine potential pro-oxidant effects and to select a concentration range lacking intrinsic toxicity suitable for studying the neuroprotective activity of the compounds, the intrinsic neurotoxic effects of each compound was evaluated following two different methods. Neurotoxicity was monitored either by quantification of cellular lysis (death), after measurement of the lactate dehydrogenase (LDH) activity released from damaged cells into the culture supernatant, or by reduction of 3-(4,5-dimethylthiazol2-yl)-2,5-diphenyltetrazolium bromide (MTT reduction assay), that allows an evaluation of the "redox state" of the cells and emphazises oxidative stress. The maximum tolerated concentration (MTC), and the concentration producing 50\% toxicity $\left(\mathrm{TC}_{50}\right.$ ), were estimated for each tested compounds using both MTT and LDH determination. 
Neuroprotective properties of alkylaminoflavone derivatives were estimated through their protective effects against $L$-homocysteic acid ( $L$-HCA) cytotoxicity. The latter has been reported to provoke, on immature primary neurons or on certain neuronal cell lines, oxidative-stress-mediated neuronal degeneration that could be attenuated with antioxidants. The concentration leading to $50 \%$ protection ( $\mathrm{PC}_{50}$ ) was estimated for both MTT and LDH determinations.

Taking into account that optimum activity was displayed by alkyl substituents in the benzophenone series $\mathbf{I I},{ }^{8}$ only were evaluated substituted alkylaminoflavones bearing isopropyl, n-propyl, isobutyl, isopentyl and allyl chains. As reported in Table, all tested flavonoids showed significant in vitro neuroprotective activity, with $\mathrm{PC}_{50}$ (MTT) values between 4.6 and $7.0 \mu \mathrm{M}$ and PC $_{50}$ (LDH) values between 4.2 and $10.0 \mu \mathrm{M}$. It could be noted that 6-alkylaminoflavones in general seemed to be slightly more active than their 8-isomers, (for example, compare $\mathbf{1 0 b}$ and $\mathbf{8 b}$ ). Nevertheless, in view of the $\mathrm{PC}_{50}$ values, it appeared that 6-alkylaminoflavones 10a-d, as well as their benzophenone analogues IIa-d, gave similar results, (for instance, compare 10a and IIa). Furthermore, as they did not exhibit a lower toxicity than that showed by their benzophenone analogues IIa-d, it could be concluded that alkylaminoflavone derivatives could not be considered as more promising compounds for therapeutic potential.

Table. In vitro neuroprotective activity of compounds 8a-e and 10a-e.<smiles>[R]Nc1c(O)cc(O[14CH])c2c(=O)cc(-c3ccccc3)oc12</smiles>

8a-e<smiles>[R]Nc1c(O)cc2oc(-c3ccccc3)cc(=O)c2c1O</smiles>

10a-e<smiles>[R]Nc1c(O)ccc(C(=O)c2ccccc2)c1OC</smiles>

II

\begin{tabular}{|c|c|c|c|c|c|c|c|}
\hline \multirow{3}{*}{ Compd } & \multirow{3}{*}{$\mathrm{R}$} & \multicolumn{4}{|c|}{ Toxicity } & \multirow{2}{*}{\multicolumn{2}{|c|}{$\begin{array}{c}\text { Protection } v s \\
2 \mathrm{mM} L \text {-HCA } \\
\mathrm{PC}_{50}(\mu \mathrm{M})\end{array}$}} \\
\hline & & \multicolumn{2}{|c|}{ MTC $(\mu \mathrm{M})$} & \multicolumn{2}{|c|}{$\mathrm{TC}_{50}(\mu \mathrm{M})$} & & \\
\hline & & MTT & LDH & MTT & $\mathrm{LDH}$ & MTT & LDH \\
\hline IIa & $\operatorname{Pr}^{\mathrm{i}}$ & 25 & 100 & 118 & $>250$ & 5.5 & 5.9 \\
\hline IIb & $\mathrm{nPr}$ & 25 & 100 & 78 & $>250$ & 5.1 & 5.1 \\
\hline IId & $\mathrm{Pe}^{\mathrm{i}}$ & 10 & 50 & 20 & 82 & 4.0 & 5.5 \\
\hline $8 \mathbf{b}$ & $\mathrm{nPr}$ & 5 & 25 & 14 & 28 & 7.0 & 8.0 \\
\hline $8 \mathrm{c}$ & $\mathrm{Bu}^{\mathrm{i}}$ & 10 & 10 & 12 & 12 & 4.6 & 4.2 \\
\hline $8 d$ & $\mathrm{Pe}^{\mathrm{i}}$ & 10 & 10 & 12 & 16 & 5.3 & 5.5 \\
\hline $8 \mathbf{e}$ & $\mathrm{CH}_{2}=\mathrm{CHCH}_{2}$ & 5 & 10 & 18 & 11 & $>5$ & $>10$ \\
\hline $10 \mathrm{a}$ & $\operatorname{Pr}^{\mathrm{i}}$ & 10 & 100 & 18 & 152 & 5.1 & 6.6 \\
\hline $10 \mathrm{~b}$ & $\mathrm{nPr}$ & 5 & 100 & 10 & 176 & 5.2 & 5.5 \\
\hline 10d & $\mathrm{Pe}^{\mathrm{i}}$ & 5 & 100 & 16 & 116 & 5.2 & 5.2 \\
\hline
\end{tabular}


Abbreviations : L-HCA, L-homocysteic acid; MTC, maximum tolerated concentration; $\mathrm{TC}_{50}$, concentration producing 50\% toxicity; $\mathrm{PC}_{50}$, concentration producing 50\% protection; $\mathrm{Bu}^{\mathrm{i}}$, isobutyl; $\mathrm{Pe}^{\mathrm{i}}$, isopentyl; $\mathrm{nPr}, \mathrm{n}$ propyl; Pri, isopropyl.

In summary, we have synthesized a series of novel 8-alkylaminoflavone derivatives from chrysine via a seven step sequence. The synthesis of their 6-alkylamino isomers could be then successfully accomplished through a convenient extension of the Wessely-Moser rearrangement. To the best of our knowledge, such a rearrangement had not been as yet reported on alkylaminoflavones. Finally, the results of our biological evaluation revealed that replacement of the benzophenone skeleton by the flavone ring did not markedly affect the neuroprotective activity in vitro.

Acknowledgment : We would like to thank Professor M.-B. Fleury, in whose laboratory this work was carried out, for his help and encouragement.

\section{References and Notes}

1. Halliwell, B.; Gutteridge, J.M.C. In Free Radicals in Biology and Medicine, Third Edition, Oxford University Press, 1999, pp. 246-350.

2. Fleury, M.-B.; Maurette, J.-M.; Largeron, M. PCT Int. Appl. WO 95 18114/1995 (Chem. Abstr. 1995, 123, 340 160x).

3. Largeron, M.; Dupuy, H.; Fleury, M.-B. Tetrahedron, 1995, 51, 4953-4968.

4. Largeron, M.; Fleury, M.-B. Tetrahedron Lett. 1998, 39, 8999-9002.

5. $\quad$ Largeron, M.; Neudorffer, A.; Fleury, M.-B. Tetrahedron Lett. 1998, 39, 5035-5038.

6. Largeron, M.; Neudorffer, A.; Fleury, M.-B. J. Chem. Soc. Perkin Trans 2, 1998, 2721-2727.

7. Larget, R.; Lockhart, B.; Pfeiffer, B.; Fleury, M.-B.; Largeron, M. Bioorg. Med. Chem. Lett. 1999, 9, 2929-2934.

8. $\quad$ Largeron, M.; Lockhart, B.; Pfeiffer, B.; Fleury, M.-B. J. Med. Chem. , 1999, 42, 5043-5052.

9. Fleury, M.-B.; Largeron, M.; Lestage, P.; Lockhart, B. ADIR and Cie Fr. Patent Appl. 9806809 May 29, 1998; PCT/FR 99/01254, May 28, 1999.

10. Bors, W.; Saran, M. Free Rad. Res. Comm. 1987, 2, 289-294.

11. Cotelle, N.; Bernier, J.-L.; Catteau, J.-P.; Pommery, J.; Wallet, J.-C.; Gaydou, E.-M. Free Rad. Biol. Med. 1996, 20, 35-43.

12. Gao, D.; Tawa, R.; Masaki, H.; Okano, Y.; Sakurai, H. Chem. Pharm. Bull. 1998, 46, 1383-1387.

13. Baker, W. J. Chem. Soc., 1933, 1381-1389.

14. Iinuma, M.; Tanaka, T., Mizuno, M. Chem. Pharm. Bull. 1987, 35, 660-667.

15. Le Floc'h, Y.; Lefeuvre, M. Tetrahedron Lett. 1986, 27, 2751-2752.

16. Cushman, M.; Nagarathnam, D. Tetrahedron Lett. 1990, 31, 6497-6500.

17. Saxena, S.; Makrandi, J.K.; Grover, S.K. Synthesis, 1985, 697-699.

18. Cushman, M.; Zhu, H.; Geahlen, R.L.; Kraker, A.J. J. Med. Chem. 1994, 37, 3353-3362.

19. Wessely, F.; Moser, G.H. Monatsh. Chem. 1930, 56, 97-105.

20. Bellamy, F.D.; Ou, K. Tetrahedron Lett. 1984, 25, 839-842.

21. Fukuyama, T.; Cheung, M.; Jow, C.K.; Hidai, Y.; Kan, T. Tetrahedron Lett. 1997, 38, 5831-5834.

22. Mitsunobu, O. Synthesis, 1981, 1-28.

23. Mukerjee, S.K.; Seshadri, T.R. Chem. Ind. 1955, 271-275 and references cited therein.

24. Donnelly, D.M. ; Philbin, E.M.; Wheeler, T.S. J. Chem. Soc. 1956, 4409-4411.

25. Philbin, E.M.; Swirski, J.; Wheeler, T.S. J. Chem. Soc. 1956, 4455-4458.

26. Seshadri, T.R. Tetrahedron, 1959, 6, 169-200 and references cited therein.

27. Shaw, S.C.; Azad, R.; Mandal, S.P.; Gandri, R.S. J. Indian Chem. Soc. 1988, 65, 107-109.

28. 5,7-dihydroxy-2-phenyl-8-propylamino-4H-1-benzopyran-4-one $8 \boldsymbol{b}:{ }^{1} \mathrm{H}$ NMR $(300 \mathrm{MHz}$, DMSO D6): $\delta 0.90\left(\mathrm{t}, 3 \mathrm{H}, \mathrm{Me}, \mathrm{nPr}, \mathrm{J}=6 \mathrm{~Hz}\right.$ ), 1.45 (sextet, 2H, $\mathrm{CH}_{2}, \mathrm{nPr}, \mathrm{J}=6 \mathrm{~Hz}$ ), 3.14 (t, 2H, 
$\left.\mathrm{N}-\mathrm{CH}_{2}, \mathrm{nPr}, \mathrm{J}=6 \mathrm{~Hz}\right), 6.33(\mathrm{~s}, 1 \mathrm{H}, 6-\mathrm{H}), 6.96(\mathrm{~s}, 1 \mathrm{H}, 3-\mathrm{H}), 7.60$ (m, 3H, H meta and $\mathrm{H}$ para, Ph), 8.10 (m, 2H, H ortho, $\mathrm{Ph}$ ), 12.50 (s , 1H, 5-OH); MS (DCI) : m/z=312( $\left.\mathrm{MH}^{+}\right)$.

5,7-dihydroxy-2-phenyl-6-propylamino-4H-1-benzopyran-4-one 10b: ${ }^{1} \mathrm{H}$ NMR (300 $\mathrm{MHz}$, DMSO D $): \delta 0.87\left(\mathrm{t}, 3 \mathrm{H}, \mathrm{Me}, \mathrm{J}=7 \mathrm{~Hz}\right.$ ), 1.43 (sextet, 2H, $\mathrm{CH}_{2}, \mathrm{~J}=7 \mathrm{~Hz}$ ), 3.20 (t, 2H, N-CH $2, \mathrm{~J}$ $=7 \mathrm{~Hz}), 6.62(\mathrm{~s}, 1 \mathrm{H}, 8-\mathrm{H}), 6.97(\mathrm{~s}, 1 \mathrm{H}, 3-\mathrm{H}), 7.56(\mathrm{~m}, 3 \mathrm{H}, \mathrm{H}$ meta and $\mathrm{H}$ para, $\mathrm{Ph}), 8.03(\mathrm{~m}, 2 \mathrm{H}$, $\mathrm{H}$ ortho, $\mathrm{Ph}), 12.50$ ( $, 1 \mathrm{H}, 5-\mathrm{OH}) ; \mathrm{MS}(\mathrm{DCI}): \mathrm{m} / \mathrm{z}=312\left(\mathrm{MH}^{+}\right)$.

29. In vitro biological assays are extensively detailed in references 7 and 8 . 


\section{A Convenient Extension of the Wessely-Moser Rearrangement for}

the Synthesis of Substituted Alkylaminoflavones as Neuroprotective Agents in Vitro

Ronan Larget ${ }^{\mathrm{a}}$, Brian Lockhart ${ }^{\mathrm{b}}$, Pierre Renard ${ }^{\mathrm{c}}$ and Martine Largeron ${ }^{\mathrm{a}}{ }^{*}$

${ }^{a}$ Laboratoire de Chimie Analytique et Electrochimie, UMR 8638 CNRS-

Université René Descartes, 4, avenue de l'Observatoire, 75270 Paris Cedex 06,

${ }^{b}$ Institut de Recherche Servier, 125 chemin de Ronde, 78290 Croissy-sur-Seine and

${ }^{c}$ ADIR, 1 rue Carle Hébert, 92415 Courbevoie Cedex, France

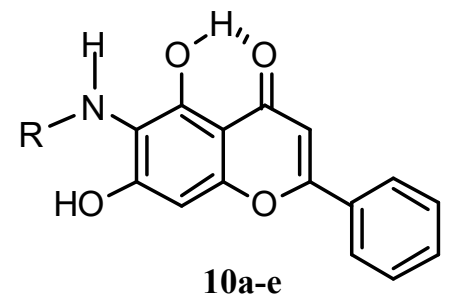

The synthesis of the title compounds, as neuroprotective agents, has been suc-

$\mathrm{R}=\mathrm{Pr}^{\mathrm{i}}, \mathrm{nPr}, \mathrm{Bu}^{\mathrm{i}}, \mathrm{Pe} \mathrm{e}^{\mathrm{i}}, \mathrm{CH}_{2}=\mathrm{CHCH}_{2}$ cessfully accomplished via the Wessely-Moser rearrangement of their 8-isome 